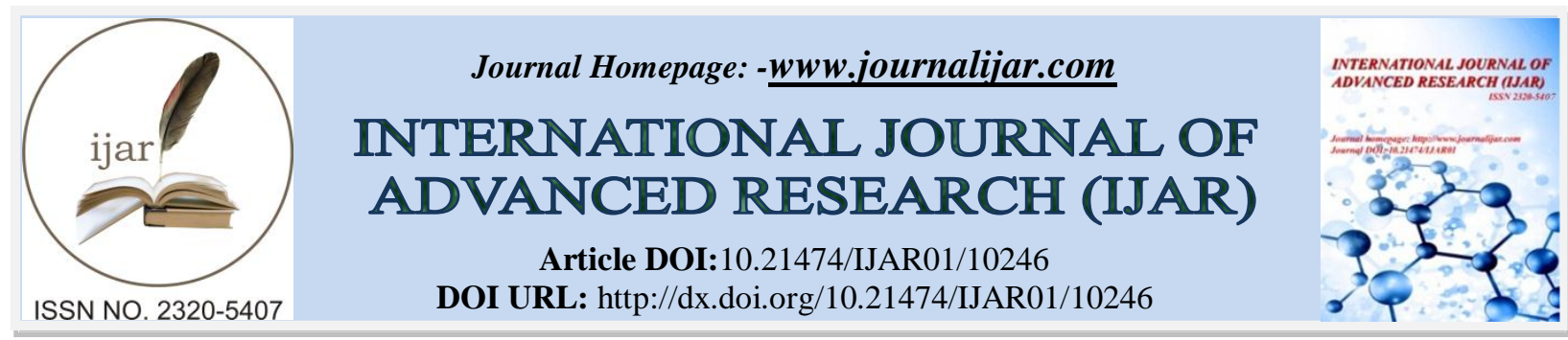

RESEARCH ARTICLE

\title{
PREVALENCE AND RISK FACTORS OF IRRITABLE BOWEL SYNDROME AMONG MEDICAL STUDENTS
}

\section{Manal Abdulaziz Murad ${ }^{1}$, Hoda Jehad Abousada ${ }^{2}$, Yazeid Mohammed Zamzami ${ }^{3}$, Malak Ahmed Alkaf ${ }^{3}$, Banan Khalid M Sagga ${ }^{3}$, Atheer Nasser Alhrany ${ }^{4}$, Ghada Ibraheem Bredy ${ }^{4}$ and Mohammed Zakaria Alhawsawi ${ }^{5}$}

1. Assistant Professor and consultant family medicine, Department of Family Medicine, faculty of medicine, king abdulaziz university, KSA.

2. Medical intern, Ibn Sina National College, KSA postal address: jeddah, Al-Thaghr neighborhood., 22338.

3. Medical interns, Ibn Sina National College, KSA.

4. Medical student, MBBS, King khalid university, KSA.

5. Medical student, MBBS, Batterjee Medical College, KSA.

\section{Manuscript Info}

Manuscript History

Received: 12 October 2019

Final Accepted: 14 November 2019

Published: December 2019

\section{Abstract}

\section{Introduction:-}

IBS is not the same as inflammatory Bowel disease (IBD), a more serious condition that causes inflammation in the digestive tract and can result in severe complications.

IBS It is considered a functional disorder in the way the stomach and intestines work, as there is no known reason for this relapsing gastrointestinal problem, characterized by abdominal pain, bloating, and changes in bowel habits. Perhaps Irritable Bowel Syndrome (IBS) is associated with life disorder, anxiety, stress, and practical stress, and this may be related to study stress, as medical students are considered more vulnerable than others to psychological disorder and chronic anxiety due to permanent study.

\section{Rationale:}

This research will be very useful because it is linked to IBS and this disease is one of the risk factors the stress, and naturally we have to ask in particular the medical students about the stress and all factors related to IBS. this will help us to determined how many medical students may affected by this disease.

\section{Literature review:}

According to this study A systematic review of the prevalence and risk factors of irritable bowel syndrome among medical students(Ibrahim, 2016).

The results was: Sixteen studies were identified, and the prevalence of IBS among medical students ranged from 9.3\% to $35.5 \%$. The relatively high prevalence among medical students may be attributed to their special stressful learning environment. Some studies found that female gender, family history of IBS, psychiatric stress, anxiety, depression, infections, dietary factors, and sleep disorders were associated with IBS. (Ibrahim, 2016)

Corresponding Author:- Hoda Jehad Abousada

Address:- Corresponding author: Medical intern, Ibn Sina National College, KSA postal address: jeddah, Al-Thaghr neighborhood., 22338. 
Similarly, in our study the focus will be on medical students because they under the pressure and stress depend on the learning environment more than other educational categories.

On the other hand in this study Assessment of Knowledge, Attitude and Practice towards Irritable Bowel Syndrome and Risk Factors in Riyadh City, 2017 (Algabr et al., 2018)

The Conclusion was: The majority of subjects had proper knowledge about the nature, prognosis and risk factors of the disease. Other studies should be conducted to measure the KAP of other Saudi population toward IBS from different regions of KSA.

This study (Algabr et al., 2018) its general study did not address the identification of a particular idea.

\section{Research Objectives:-}

The Aim: determine the prevalence and risk factors of IBS among medical students.

\section{Objective:-}

1. Identify the IBS disease most common among males or females.

2. Determine the most affected age group for IBS.

3. To identify the most prevalent risk factors.

4. To determine the extent of intellectual awareness about the severity of the disease.

\section{Methodology:-}

Study design:

This is an analytical cross-sectional study.

\section{Study Setting and period:}

This is an analytical cross-sectional study conducted at Universities and hospitals (from the medical students), KSA from may 2019 till November 2019.

\section{Study population and sampling:}

Study participants:

Inclusion criteria; All medical students. Exclusion criteria; non-medical students.

\section{Sampling Method:-}

Participants will be especially from medical universities and colleges selected and carried out by questionnaire.

\section{Sampling size:}

Sample size was calculated using OpenEpi for sample size calculation for cross sectional studies, hypothesizing the true answers Accordingly, 2201 participants were gathered from the medical students. score of prevalence of who suffering from stomach, gut and bowel problems $49.93 \%$ from the number of responses and the 1411 females' responses from the total number of sample.

According to the prevalence study, $64.11 \%$ of participants females, $57.56 \%$ between $21-24$ year old, $80.37 \%$ nonsmokers, $95.05 \%$ don't suffer from hypertension, $95.64 \%$ non-diabetic, $65.83 \%$ don't have depression , $61.79 \%$ don't have emotional distress, 49.93 suffer from stomach, gut and bowel problems.

\section{Measurements:}

\section{Explanatory variables:}

1. Sociodemographic characteristics: gender, age, nationality.

2. Disease-related information: risk factors, the type of dealing with the disease in terms of seriousness, presence of complications and associated disease, etc.

\section{Outcome measures:}

The outcome measure is by counting the ratio of the number of medical students have risk factors of IBS this will be 


\section{Measured using:}

By determining the extent of the disease in addition to the risk factors that lead to suffering from IBS.

\section{Prevalence study:}

will be carried to test the questionnaire if easily understood and the response of the participants. Data from the crosssectional study will be used to calculate the sample size.

\section{Data Management and Analysis plan:}

Data will be entered and analyzed using SPSS version 17.0 Descriptive statistics will be performed and categorical data will be displayed as frequencies and percentages while measures of central tendencies and measures and dispersion will be used to summarize continuous variables. Univariate and multivariate analysis will be performed to investigate association between exposure factors gender, age, nationality, risk factors, the type of dealing with the disease in terms of seriousness, presence of complications and associated disease. statistical significance is set at a $\mathrm{P}$ value of 0.05 or less.

\section{Statistical analysis:}

Data were entered and analyzed using Statistical Package for the Social Sciences (SPSS) version 17. Descriptive statistics were displayed as frequencies and percentages for categorical variables. Measures of central tendencies (the median), and measures and dispersion (minimum - maximum) were used to summarize continuous variables, as the continuous variables were not normally distributed when tested by Shapiro-Wilk test. Univariate analysis was performed to investigate the association between the exposure factors ( gender, age, nationality, risk factors, the type of dealing with the disease in terms of seriousness, presence of complications and associated disease), with the outcome on the one hand, receiving the cure, and on the way of looking at this health problem. This was performed using Chi-squared test and Mann-Whitney test. Multivariate analysis to investigate factors independently was performed using binary logistic regression. P value was set at a significance level of $<0.05$.

\section{Results:-}

In this study, the aim was to determine determine the prevalence and risk factors of IBS among medical students, 2201 participants and 1411 of them females, were consecutively recruited from outpatient clinics, during a period from $29 / 5 / 2019$ to $17 / 11 / 2019$

Socio-demographic characteristics of the studied group ,64.11\% females, $57.56 \%$ between age 21 -24-year-old, most of the participants were Saudis $93.50 \%$. According to risk factors of disease $80.37 \%$ non-smokers, $95.05 \%$ nonhypertensive, $95.64 \%$ non-diabetic, $65.83 \%$ don't suffer from depression, $61.79 \%$ don't have emotional distress, $61.20 \%$ don't have headache, $49.93 \%$ they have gut, stomach and bowel problems, $75.74 \%$ don't have food sensitivity, $75.60 \%$ they didn't use the laxative drugs befor, $93.18 \%$ they don't use anti-depressant drugs, $85.32 \%$ don't use antibiotic frequently, $91.59 \%$ don't suffer from diarrhea with blood or mucous, 94.50 they don't have any auto immune disease, $55.57 \%$ think it's a serious problem.

\section{Correlations:}

Table 1:- $\mathrm{P}$ value is 0.010 , which means there is a strong relationship between smoking and having emotional distress.

\begin{tabular}{|c|c|c|c|}
\hline \multicolumn{4}{|c|}{ Correlations } \\
\hline & & $\begin{array}{c}\text { Do you have } \\
\text { emotional } \\
\text { distress? }\end{array}$ & $\begin{array}{l}\text { Do you } \\
\text { smoke? }\end{array}$ \\
\hline \multirow{3}{*}{$\begin{array}{l}\text { Do you have emotional } \\
\text { distress? }\end{array}$} & Pearson Correlation & 1 & $.055^{x}$ \\
\hline & Sig. (2-tailed) & & .010 \\
\hline & $N$ & 2201 & 2201 \\
\hline \multirow[t]{3}{*}{ Do you smoke? } & Pearson Correlation & $.055^{x}$ & 1 \\
\hline & Sig. (2-tailed) & .010 & \\
\hline & $N$ & 2201 & 2201 \\
\hline
\end{tabular}


Table 2:- $\mathrm{P}$ value is 0.004 , which means there is a strong relationship between having diabetes and having stomach, gut and bowel problems such as heartburn, acid stomach, flatulence, diarrhea, constipation.

\begin{tabular}{|c|c|c|c|}
\hline \multicolumn{4}{|c|}{ Correlations } \\
\hline & & $\begin{array}{l}\text { Do you have } \\
\text { Diabetes? }\end{array}$ & $\begin{array}{l}\text { Do you have } \\
\text { stomach, gut } \\
\text { and bowel } \\
\text { problems } \\
\text { such as } \\
\text { heartburn, } \\
\text { acid stomach, } \\
\text { flatulence, } \\
\text { diarrhea, } \\
\text { constipation? }\end{array}$ \\
\hline \multirow[t]{3}{*}{ Do you have Diabetes? } & Pearson Correlation & 1 & $.061^{\pi \pi}$ \\
\hline & Sig. (2-tailed) & & .004 \\
\hline & $N$ & 2201 & 2178 \\
\hline \multirow{3}{*}{$\begin{array}{l}\text { Do you have stomach, gut } \\
\text { and bowel problems } \\
\text { such as heartburn, acid } \\
\text { stomach, flatulence, } \\
\text { diarrhea, constipation? }\end{array}$} & Pearson Correlation & $.061^{x \pi}$ & 1 \\
\hline & Sig. (2-tailed) & .004 & \\
\hline & $\mathbb{N}$ & 2178 & 2178 \\
\hline
\end{tabular}

Table 3:- $\mathrm{P}$ value is 0.002 , which means there is a strong relationship between having depression and having emotional distress.

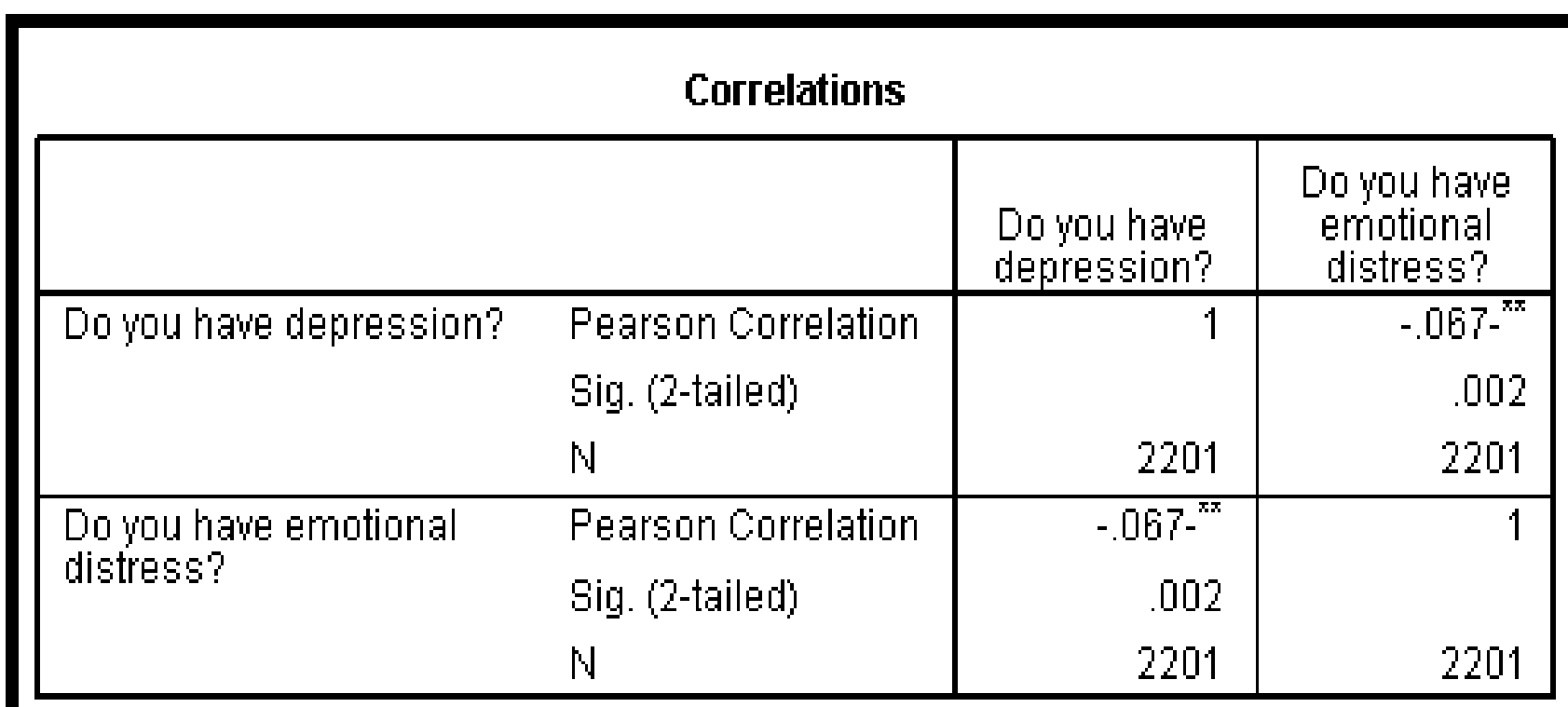

*. Correlation is significant at the 0.01 level (2-tailed). 
Table 4:- $\mathrm{P}$ value is 0.000 , which means there is a strong relationship between having diabetes having autoimmune disease.

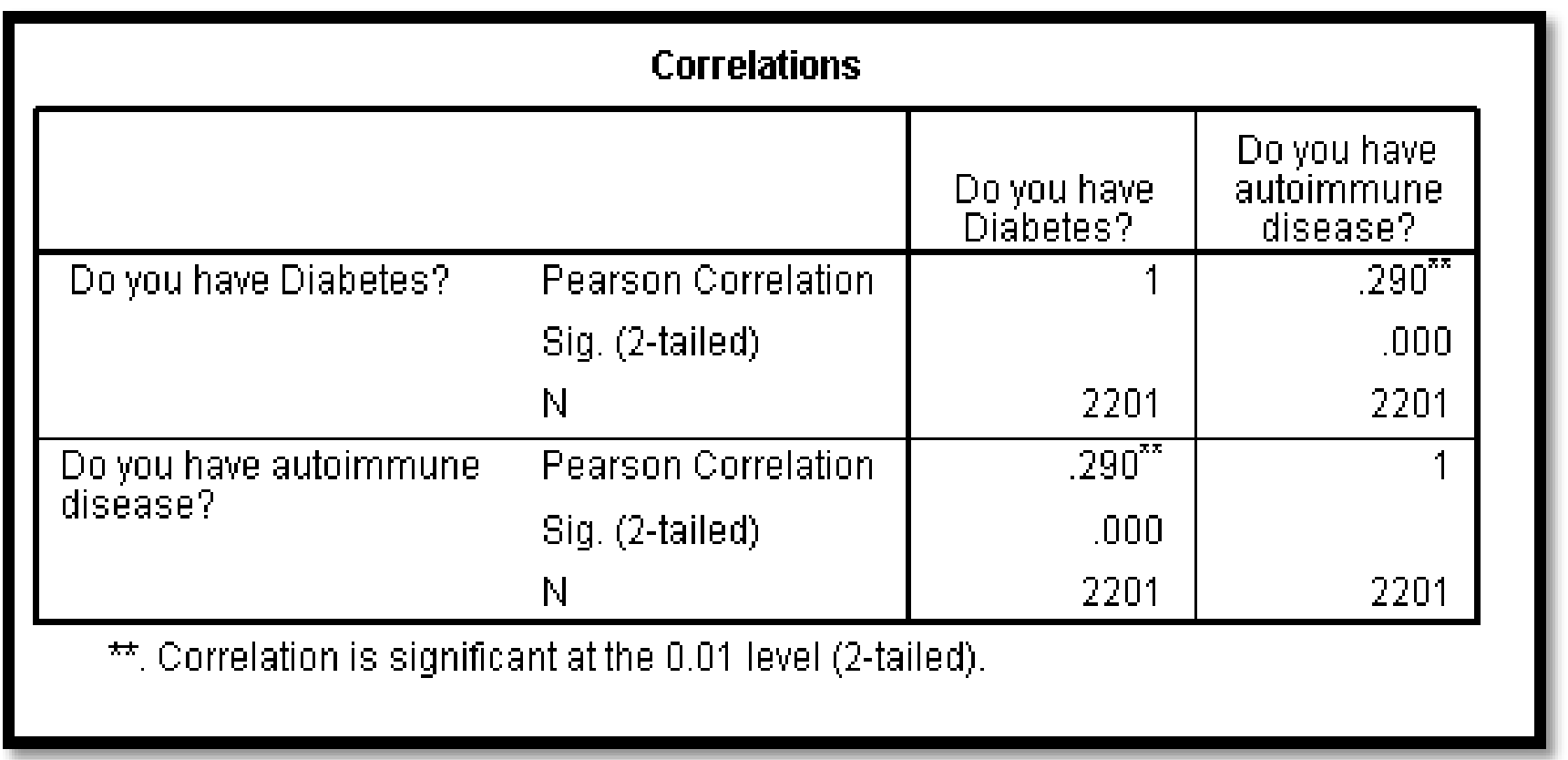

Table5:- $\mathrm{P}$ value is 0.005 , which means there is a strong relationship between having emotional distress and using antibiotic frequently.

\section{Correlations}

\begin{tabular}{|c|c|c|c|}
\hline & & $\begin{array}{l}\text { Do you use } \\
\text { aritibiotic } \\
\text { freguently? }\end{array}$ & $\begin{array}{c}\text { [o you have } \\
\text { emotional } \\
\text { distress? }\end{array}$ \\
\hline \multirow{3}{*}{$\begin{array}{l}\text { Do you use antibiotic } \\
\text { frequently? }\end{array}$} & Pearson Coreatation & 1 & $.060^{\pi x}$ \\
\hline & Sig. (2-tailed) & & 005 \\
\hline & N & 2201 & 2201 \\
\hline \multirow{3}{*}{$\begin{array}{l}\text { Do you have emotional } \\
\text { distress? }\end{array}$} & Pearson Correlation & $.060^{\pi x}$ & 1 \\
\hline & Sig. (2-tailed) & 005 & \\
\hline & N & 2201 & 2201 \\
\hline
\end{tabular}

*. Correlation is significant at the 0.01 level (2-tailed). 
Table 6:- $\mathrm{P}$ value is 0.000 which means there is a strong relationship between having diarrhea with blood or mucous and using the laxatives drugs.

\begin{tabular}{|ll|r|r|}
\hline \multicolumn{3}{|c|}{ Correlations } \\
\hline \multicolumn{1}{|c|}{} & $\begin{array}{c}\text { Do you have } \\
\text { diarhea with } \\
\text { blood or } \\
\text { mucous? }\end{array}$ & $\begin{array}{c}\text { Did you use } \\
\text { before the } \\
\text { laxatives } \\
\text { drugs? }\end{array}$ \\
\hline $\begin{array}{l}\text { Do you have diarrhea with } \\
\text { blood or mucous? }\end{array}$ & Pearson Correlation & 1 & $.129^{\text {xx }}$ \\
& Sig. (2-tailed) & 2201 & .000 \\
\hline $\begin{array}{l}\text { Did you use before the } \\
\text { laxatives drugs? }\end{array}$ & Pearson Correlation & $.129^{\mathrm{x}}$ & 2201 \\
\hline & Sig. (2-tailed) & .000 & 1 \\
& $\mathrm{~N}$ & 2201 & 2201 \\
\hline
\end{tabular}

$*$ Correlation is significant at the 0.01 level (2-tailed).

\section{Discussion:-}

This study was based on a number of 2201 participants, from this study as the number of females is 1411 and males is 790 and ,1099 of them have stomach, gut and bowel problems which is considering as unhealthy sign requires going to the doctor for a health check-up, on the otherwise the most of risk factors related to IBS in this study didn't given clear or strong results.

The current study showed statistically significant ( $\mathrm{P}$ value is 0.010 ) which means there is a strong relationship between smoking and having emotional distress this means that smoking and emotional distress may constitute an important impact on the risk factors of IBS, ( $\mathrm{P}$ value is 0.004) which means there is a strong relationship between having diabetes and having stomach, gut and bowel problems such as heartburn, acid stomach, flatulence, diarrhea, constipation on the other hand, this can be considered related to diabetes medications that may be accompanied by problems in stomach, gut and bowel.

( $\mathrm{P}$ value is 0.002) which means there is a strong relationship between having depression and having emotional distress and that is very logical, ( $\mathrm{P}$ value is 0.000 ) which means there is a strong relationship between having diabetes and having autoimmune disease, there is a strong relationship between having emotional distress and using antibiotic frequently ( $\mathrm{P}$ value is 0.005 ) which means it may be a side effect of the antibiotic, ( $\mathrm{P}$ value is 0.000) which means there is a strong relationship between having diarrhea with blood or mucous and using the laxatives drugs it may also be considered as a side effect of this medication.

\section{Conclusion:-}

The study findings show that this disease not common in medical students, this was clarified by the participants answers to the risk factors questions, although there is a large proportion of participants suffer from stomach, gut and bowel problems but this. may be due to other diseases, the positive things most of them are non-smokers this forms a direct relationship with the probability of occurrence of IBS, it is recommended to provide healthcare workers with launch specific awareness programs on not neglecting the irritable bowel syndrome and effective of ease of treatment and methods.

Replication of this study in multiple hospitals or areas across different caregiver stuff is recommended, thus making IBS problem in the domain of evidence-based medicine. 


\section{Recommendation:-}

we recommend setting up health education programs about the irritable bowel syndrome This health problem must be presented broadly and beneficially and, in a way, that everyone understands, as most deal with the IBS by ignoring and not being important, work should be done on health conferences and medical discussions on that.

\section{Acknowledgement:-}

The authors would like to thank the participants for their great cooperation, Participants will be especially from medical universities and colleges selected and carried out by questionnaire.

We thank the data collectors: Hend Hamdan Alamri, Rahaf Ahmed Alamer, Yara Mohmmed O.Akbar, Nieveen Abdullah Tunkar, Aghareed Mohammed Asali and lujain ahmed faraj who collected the data from the medical students, they worked hard to collect data greatly, and a large sample number was collected for their great effort.

\section{Ethical considerations:}

Administrative approval will be sought from the unit of biomedical ethics research committee Ethical approval will be sought from the ethical committee of the faculty of medicine, king abdulaziz university. An informed consent will be sought from the participants.

\section{Source of funding, self-funded:-}

This research did not receive any specific grant from funding agencies in the public, commercial, or not-for-profit sectors.

\section{References:-}

1. Soubieres A, Wilson P, Poullis A, Wilkins J and Rance M (2015): Burden of irritable bowel syndrome in an increasingly cost-aware National Health Service. Frontline gastroenterology, 6:246-251.

2. Saha L (2014): Irritable bowel syndrome: Pathogenesis, diagnosis, treatment, and evidencebased medicine. World Journal of Gastroenterology, 20:6759-6773.

3. Algabr, G., Alotaibi, T., Alshaikh, A., Maimani, Y. and AlShehri, M. (2018). Assessment of Knowledge, Attitude and Practice towards Irritable Bowel Syndrome and Risk Factors in Riyadh City, 2017. [online] Eds.a.ebscohost.com.sdl.idm.oclc.org. Available at: http://eds.a.ebscohost.com.sdl.idm.oclc.org/eds/pdfviewer/pdfviewer?vid=2\&sid=6ffc8412-8429-463e-8a0fef9f632c94fb\%40sdc-v-sessmgr01 [Accessed 1 Jan. 2018].

4. Al-Hazmi AH (2012): Knowledge, Attitudes, and Practices of Primary Care Physicians About Irritable Bowel Syndrome in Northern Saudi Arabia. Saudi Journal of Gastroenterology : Official Journal of the Saudi Gastroenterology Association, 18:173-181

5. Nellesen D, Yee K, Chawla A, Lewis BE and Carson RT (2013): A systematic review of the economic and humanistic burden of illness in irritable bowel syndrome and chronic constipation. Journal of managed care pharmacy, 19:755-764

6. Ibrahim, N. (2016). A systematic review of the prevalence and risk factors of irritable bowel syndrome among medical students. [online] Eds.a.ebscohost.com.sdl.idm.oclc.org. Available at: http://eds.a.ebscohost.com.sdl.idm.oclc.org/eds/pdfviewer/pdfviewer?vid=2\&sid=794e3e68-5166-474d-aea9e3ab94d7fd36\%40sdc-v-sessmgr03 [Accessed 1 Jan. 2016].

7. Konig J, Brummer RJ. Alteration of the intestinal microbiota as a cause of and a potential therapeutic option in irritable bowel syndrome. Benef Microbes 2014; 5: 247-61.

8. Saito YA, Petersen GM, Larson JJ, et al. Familial aggregation of irritable bowel syndrome: a family casecontrol study. Am J Gastroenterol 2010; 105: 833-41.

9. Heitkemper MM, Kohen R, Jun SE, Jarrett ME. Genetics and gastrointestinal symptoms. Annu Rev Nurs Res 2011; 29: 261-80.

10. Heitkemper M, Jarrett M, Jun SE. Update on irritable bowel syndrome program of research. J Korean Acad Nurs 2013; 43: 579-86.

11. El-Salhy M, Gundersen D. Diet in irritable bowel syndrome. Nutr J 2015; 14: 36.

12. Zheng Z, Huang C, Guo Y, et al. Staple foods consumption and irritable bowel syndrome in Japanese adults: a cross-sectional study. PLoS One 2015; 10: e0119097.

13. Barrett JS, Gibson PR. Fermentable oligosaccharides, disaccharides, monosaccharides and polyols (FODMAPs) and nonallergic food intolerance: FODMAPs or food chemicals? Therap Adv Gastroenterol 2012; 5: 261-8 
14. Han SH, Lee OY, Bae SC, et al. Prevalence of irritable bowel syndrome in Korea: population-based survey using the Rome II criteria. J Gastroenterol Hepatol. 2006;21:1687-1692. [PubMed] [Google Scholar] .

15. Murray CD, Flynn J, Ratcliffe L, Jacyna MR, Kamm MA, Emmanuel AV. Effect of acute physical and psychological stress on gut autonomic innervation in irritable bowel syndrome. Gastroenterology. 2004;127:1695-1703. [PubMed] [Google Scholar]

Appendices: (Questionnaire):-

Prevalence and Risk Factors of Irritable Bowel Syndrome Among Medical Students:

انتشار وعوامل الخطر لمتلازمة القولون العصبي بين طلاب الطب.

1. الجنس : Gender:

ذ النكر

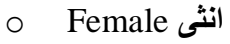

2. Age: العمر

○ $18-20$

○ $21-24$

○ $25-28$

3. Nationality: الجنسية

مسودي / saudi

غير سعودي / non saudi

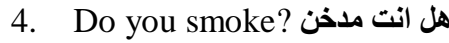

ن نع

○ No ע

5. Do you have Hypertension? لايكت ارتفاع في الضغ

- Yes

○ No ע

6. Do you have Diabetes? لديك مرض السكري

ن نعم Yes

○ No ע

7. Do you have depression? هل تعاني من الاكتئاب

- Yes نعم

○ No ע

8. Do you have emotional distress? له لايك اضطراب عاطفي

O Yes

○ No ע

9. Do you suffer from frequent Headaches? هلاني من الصداع المتكرر

- Yes نعم

○ No ע

10. Do you have stomach, gut and bowel problems such as heartburn, acid stomach, flatulence, diarrhea, هل تعاني من مشاكل في المعدة والأمعاء مثل حرقان في المعدة وحموضه وانتفاخ البطن والإسهال والإمساك؟ constipation?

○ Yes

○ No ע

11. Do you have any foods sensitivity? هل لايك حساسية تجاه طعام معين

- Yes

○ No ע

12. Did you use before the laxatives drugs for constipation ? هل استخدمت من قبل ادوية المسهلات ( الملين ) في حالات الامساك

ن نع

○ No ע

13. Did you use antidepressant drugs? (هل تستخدم ادوية مضادة للإكتاب)

○ نع ن Yes

○ No ע

14. Do you use antibiotic frequently? هل تستخدم المضادات الحيوية بشكل متكرر؟

○ نع

○ No ע

15. Do you have diarrhea with blood or mucous in stools ? لد لايك اسهال مع وجود دم او مخاط في البراز

- Yes

○ No ע 
16. Do you have autoimmune disease? هل لايك مرض في الجهاز المناعي

ن بes

○ No ע

17. In your opinion the Irritable Bowel Syndrome is a serious condition? برأيك هل متلازمة القولون العصبي حالة خطيرة؟ ن Yes

○ No ע 